\title{
Portfolio Analysis Using the Single Index Method in the COVID-19 Pandemic Period
}

\author{
Sulistyo Adi Nugroho', Tony Irawan SE MappEc ${ }^{1}$, Ir Aruddy, Msi ${ }^{1}$ \\ ${ }^{1}$ IPB University, School of Business, Jl. Raya Pajajaran Bogor, Indonesia \\ Corresponding Author: Sulistyo Adi Nugroho
}

\begin{abstract}
The COVID-19 outbreak that occurred in early 2020 put pressure on economic activity in many countries, including Indonesia. The pressure on economic activity can be seen from the index movement in the capital market. The JCI as a composite index that reflects transaction activity in the Indonesian capital market has weakened due to the impact of the COVID-19 outbreak in a number of business sectors. The decline in the index is a warning for investors to rearrange the composition of assets in their portfolios so that returns can remain optimal during a pandemic. The single index model (SIM) can be used by investors to make investment decisions, including to rearrange their investment portfolios. The share price data analyzed covers the period from 2 September 2019 to 7 December 2020, where the government confirmed the first positive case of COVID-19 in Indonesia on 3 March 2020. The Single Index Model is used to select assets to form an optimal portfolio. Portfolio performance is measured using the Sharpe, Treynor and Jensen index. The sector rotation strategy results in five selected sectors whose assets will be selected to form an optimal portfolio, namely the consumption sector (JKCONS), the basic and chemical industry sector (JKBIND), the infrastructure sector (JKINFA), the mining sector (JKMING) and the financial sector (JKFINA). The listed companies for analysis were 25 out of 184 issuers in the five sectors. The Single Index Model selects 3 issuers for the pre-COVID period and 10 issuers for the COVID period. The allocation of portfolio funds for the preCOVID period showed BTPS of 44.94\%; CPIN $47.61 \%$ and BYAN $7.46 \% .2 .8 \%$ allocation of portfolio funds during the COVID period to BTPS issuers; PBID 22.57\%; TKIM 15.96\%;
\end{abstract}

BYAN 5.86\%; ITMG $17.89 \%$; MYOH $1.56 \%$; PTBA $1.76 \%$; ADRO $12.54 \%$ and PPRE $19.05 \%$. The portfolio's expected return is positive, which means that the portfolio formed has the potential to generate profits. The Sharpe, Treynor and Jensen indexes are positive, which means that portfolios formed using a single index model have the potential to have good performance.

Keywords: investors, IHSG, portfolio performance, single index model, optimal portfolio

\section{INTRODUCTION}

In 2020, the COVID-19 outbreak emerged which caused the world economy to experience changes where these changes affected movements in the capital market. The effect of these fluctuations in the capital market resulted in a decline in stock exchanges in the world. Indonesia is one of the countries experiencing the effects of these capital market movements. As of March 2, 2020, President Jokowi announced that the first positive case of COVID-19 in Indonesia led to a policy of restricting community activities.

The effect of the policy of restricting public activities led to a decline in the price of the JCI. This declining condition occurred in line with increasing investor concerns about the impact of the COVID-19 outbreak on national economic growth. Thus, there is risk aversion by investors in line with the increasing cases of COVID-19 (Pebrianto 2020). The decline in the JCI reflects a decline in the performance of the 
economic sector due to the COVID-19 outbreak, which is considered to have disrupted the global economy.

Over time, the performance of the Composite Stock Price Index tends to be bullish or has an increasing trend. The increase was due to new normal conditions where several policies were relaxed including investment activities (Tambunan 2020). This condition has also gradually made the wheels of Indonesia's domestic economy slowly turn back so that it has the opportunity for economic recovery. The news of the arrival of the COVID-19 vaccine made the Indonesian stock market go even better. The news became a positive catalyst that was responded by market participants (Sidik 2020).

The JCI as an indicator of the Indonesian capital market index is used by investors as a reference for price developments and portfolio preparation. As a result of the JCI stock price movement which is still volatile during the COVID-19 period, investors are often faced with the problem of uncertainty in choosing which stocks to form into a portfolio. This depends on the risk preferences of the investors themselves, but a rational investor will choose the optimal portfolio (Jogiyanto 2010).

The optimal portfolio can be formed by applying a single index model (Elton and Gruber 1995) and abbreviated as MIS. The Single Index Model is a model developed by Sharpe (1963) as a simplification of the Markowitz model (1952). The Single Index Model can also be used to calculate the expected return and portfolio risk. This model can be used by investors as a tool in making investment decisions (Anggraeni and Mispiyanti 2020). Single index model can be used to form an optimal portfolio by eliminating stocks that are considered less efficient based on the ratio of risk and return.

The COVID-19 outbreak causes future economic uncertainty which has an impact on stock movements in each issuer of the Jakarta Composite Index (JCI) to be uncertain. The uncertain movement also has an impact on the performance of sectoral indexes.

Markowitz's modern portfolio theory issues the concept of diversification of investment portfolios. If one of the investor's stock portfolios is down, the other stocks will not experience it. Thus, investors are advised to choose the optimal portfolio by considering the characteristics of the risk and return of the portfolio on the stocks to be invested. One of the answers to the optimal portfolio itself is the Single Index Model approach or method.

The Single Index Model is a measuring tool for measuring a portfolio that has a low risk developed by Sharpe (1963) and can also be used to calculate the expected return and portfolio risk. This model can also provide an overview for investors to make a reference in making investments (Anggraeni and Mispiyanti 2020). In addition, this method can also be used to form an optimal portfolio and also eliminate stocks that are considered less efficient based on the ratio of risk and return.

The Single Index model has a weakness where the assumption used is the movement of stock prices along with market prices. This assumption implies that the securities move simultaneously with the movement of the market index. The Single Index Model involves two main components, namely the return component related to the uniqueness of the company $(\alpha)$ and the return component related to the market or systematic risk ( $\beta$ ) (Tandelilin 2010).

Based on the description above, the impact of the COVID-19 pandemic on activities in a number of economic sectors and investors should form an optimal investment portfolio, there are problems that need to be answered through this research, namely:

1. What is the strategy for compiling an optimal portfolio in the period affected by the COVID-19 pandemic? 
2. How does the performance of selected stock portfolios compare before and during the COVID-19 pandemic?

\section{METHODS}

Sector rotation strategy is an investment strategy that is expected to generate higher returns compared to other investment strategies by shifting more weight to sectors that are predicted to perform better (Ambarita and Soekarno 2013). The idea in managing a portfolio that implements a sector rotation investment strategy is to shift the weight of the portfolio to the industry or sector that is expected to perform better.

Sector rotation strategy is a strategy that is based on the business cycle by predicting what sector will perform compared to other sectors. As the economy moves forward, various business sectors tend to perform better than others. The performance of these sectors can be a factor in the stages of the business cycle.

The Single Index Model (MIS) is a simplification of the Markowitz model (Jogianto 2003). The Single Index Model is based on the theory that individual stock price movements will follow market stock price movements (market index) (Jogianto 2003). In general, it can be observed that the stock price is likely to increase if the price of the Stock Price Index (IHS) rises. Conversely, if the IHS lowers the price of most of the shares then the stock price declines.

According to Bawasir and Sitanggang (1994), the single index method can be used in determining the optimal portfolio by comparing the excess return to beta (ERB) with the cut-off-rate (Ci). The optimal portfolio is formed by stocks that have an $\mathrm{E}(\mathrm{Ri})$ value greater than the RBR so that a positive Excess Return to Beta (ERB) value is obtained (Rahmasita et al 2014).

\section{Stock return;}

$R_{i}=\frac{P_{t}-P_{t-1}}{P_{t-1}}($ Jogiyanto 2011)

Information:
$R_{\tilde{i}} \quad=$ Return of the $\mathrm{i}$ th stock

$P_{t}=$ Stock price in period $\mathrm{t}$

$P_{t-1}=$ Stock price in the previous period

\section{Stock expected return;}

$E\left(R_{i}\right)=\frac{\Sigma_{j=1}^{n} \cdot R_{i j}}{n}($ Zubir 2011)

Information:

$E\left(R_{i}\right) \quad=$ expected return of the $i$ th stock

$\Sigma_{t=1}^{n} \cdot R_{i j}=$ Stock return $\mathrm{i}$ in period $\mathrm{j}$

$n \quad=$ Number of periods

\section{Stock risk;}

$\sigma_{i^{2}}=\frac{\Sigma_{t=1}^{n}\left[R_{i}-E\left(R_{i}\right)\right]^{2}}{n}($ Zubir 2011)

Information:

$\sigma_{i^{2}}=$ Stock variance

4. Market return;

$R_{m t}=\frac{I H S G_{t}-I H S G_{t-1}}{I H S G_{t-1}}($ Jogiyanto 2011)

Information:

$R_{m} \quad=$ Market profit rate in period $\mathrm{t}$

IHSG $G_{t}=$ The value of the closing index in the $\mathrm{t}$ - th month

$I H S G_{t-1}=$ The value of the closing index in the month to $\mathrm{t}-1$

\section{Market expected return;}

$E\left(R_{m}\right)=\frac{\Sigma_{t=1}^{n} \cdot R_{m}}{n}$

Information:

$E\left(R_{m}\right)=$ Expected market rate of profit

$n \quad=$ Period

6. Market risk;

$\sigma_{m}^{2}=\frac{\sum_{t=1}^{n}\left[R_{m}-E\left(R_{m}\right)\right]^{2}}{n}$

Keterangan:

$\sigma_{m}^{2}=$ Market variance

\section{Stock beta;}

$\beta_{i}=\frac{\sigma_{i m}}{\sigma_{m}^{2}}$

$\beta_{i}=\frac{\Sigma_{t=1}^{n}\left[\left(R_{i t}-E\left(R_{i}\right)\left(R_{m}-E\left(R_{m}\right)\right]\right.\right.}{\Sigma_{t=1}^{n}\left[R_{m}-E\left(R_{m}\right)\right]^{2}}$

(Jogiyanto 2010)

Keterangan:

$\beta_{i}=$ Stock beta 
8. Stock Alpha;

$\alpha_{i}=E\left(R_{i}\right)-\left(B_{i}, E\left(R_{m}\right)\right)$

(Jogiyanto 2010)

Keterangan:

$\alpha_{\bar{i}_{\bar{i}}}=$ Stock alpha

\section{Residual variance;}

$\sigma_{e i}^{2}=\sigma_{i}^{2}-\left(\beta_{i}^{2} \cdot \sigma_{m}^{2}\right)($ Jogiyanto 2010)

Information:

$\sigma_{e i}^{2}=$ The variance of the security residual error to $\mathrm{i}$

$\sigma_{i}^{2}=$ Stock variants i

\section{Excess return to beta (ERB);}

$E R B_{i}=\frac{E\left(R_{i}\right)-R_{B R}}{\beta_{i}}($ Jogiyanto 2010)

Keterangan:

$E R B_{i}=$ Excess return to beta stock $\mathrm{i}-\mathrm{i}$

$R_{B R}=$ Risk-free asset return

Cut-off rate;

$C_{i}=\frac{\sigma_{m}^{2} \cdot \Sigma_{i=1}^{n} \cdot A_{i}}{1+\sigma_{m}^{3} x_{i=1}^{1} \cdot B_{i}} ; \quad A_{i}=\frac{\left[E\left(R_{i}\right)-R_{B R}\right] \cdot \beta_{i}}{\sigma_{e i}^{3}}$

$B_{i}=\frac{\beta_{i}^{2}}{\sigma_{e i}^{2}}$

\section{Stock proportion;}

$W_{i}=\frac{X_{i}}{\Sigma_{i=1}^{k} X_{i}} ; \quad X_{i}=\frac{\beta_{i}}{\sigma_{e i}^{2}}(E R B-C *)$

Keterangan:

$W_{i}=\mathrm{i}$-th share proportion

$k=$ The number of stock in the optimal portfolio

12. SIM portfolio expected return;

$$
\begin{aligned}
& E\left(R_{p}\right)=\alpha_{p}+\beta_{p} E\left(R_{m}\right) \\
& \alpha_{p}=\Sigma_{i=1}^{n} \text { wi. } \alpha_{i} \\
& \beta_{p}=\Sigma_{i=1}^{n} \text { wi. } \beta_{i}
\end{aligned}
$$

\section{Portofolio risk;}

$$
\sigma_{p}^{2}=\beta_{p}^{2} \cdot \sigma_{m}^{2}+\Sigma \cdot w i^{2} \cdot \sigma_{e i}{ }^{2}
$$

\section{RESULTS}

\section{Selected Sectors}

The calculation results for the selection of Sector Rotation obtained an average return for each sectoral index. Research conducted by Ambarita and Soekarno (2013) uses the average return to determine the objectives of the strategic sector itself, namely looking for sectors that have the best performance from other sectors. The ranking and average value of sectoral index returns can be seen in Table 1.

Table 1 The average return on the Indonesian sectoral index for the period 3 March - 7 December 2020

\begin{tabular}{|l|l|c|}
\hline Rating & Sectoral Index & Average Return (\%) \\
\hline 1 & Mining & 0,1816 \\
\hline 2 & Basic Industry & 0,1536 \\
\hline 3 & Agriculture & 0,1190 \\
\hline 4 & Finance & 0,0776 \\
\hline 5 & Consumer goods & 0,0766 \\
\hline 6 & Miscellaneous & 0,0495 \\
\hline 7 & Infrastructure & 0,0478 \\
\hline 8 & Trade & 0,0475 \\
\hline 9 & Property & $-0,0308$ \\
\hline
\end{tabular}

Determination of the selected sector for the sector rotation strategy also uses the value of market sensitivity $(\beta)$ to describe the response of an asset instrument to shocks or shocks that occur systemically. The basis for determining the minimum value is the average value of the overall market sensitivity value $(\beta)$. Research conducted by Fajri (2019) uses market sensitivity $(\beta)$ to determine which sectoral indices are cyclical and non-cyclical sectors in the implementation of the sector rotation strategy. The market sensitivity value of the Indonesian sectoral index for the period 3 March - 7 December 2020 can be seen in table 2 .

Table 2 The value of the market sensitivity of the Indonesian sectoral index for the period 3 March - 7 December 2020

\begin{tabular}{|l|l|c|}
\hline Rating & \multicolumn{1}{|c|}{ Sectoral } & Market Sensitivity $(\boldsymbol{\beta})$ \\
\hline 1 & Finance & 1,1555 \\
\hline 2 & Miscellaneous & 1,1375 \\
\hline 3 & Basic Industry & 1,1330 \\
\hline 4 & Infrastructure & 1,0825 \\
\hline 5 & Consumer Goods & 0,9854 \\
\hline 6 & Agriculture & 0,7991 \\
\hline 7 & Property & 0,7523 \\
\hline 8 & Mining & 0,7240 \\
\hline 9 & Trade & 0,5477 \\
\hline
\end{tabular}

The determination of the next sector uses the stock market capitalization value. According to Mulyono (2015), changes in the capitalization value can be influenced by changes in prices and issuance or a reduction in the number of shares on the stock exchange. The high performance of the financial sector during the pandemic is inseparable from the policy of the Financial Services Authority (OJK) issuing policies to 
reduce market volatility, provide space for the real sector to survive and maintain overall financial system stability (Sitanggang 2021). The development of stock trading by sector in the second week of December 2020 can be seen in table 3.

Table 3 Development of stock trading by sector December second week of 2020

\begin{tabular}{|l|l|c|c|}
\hline Rating & \multicolumn{1}{|c|}{ Sectoral } & $\begin{array}{c}\text { Market } \\
\text { Capitalization } \\
\text { Value (Rp } \\
\text { Trillion) }\end{array}$ & $\begin{array}{c}\text { Market } \\
\text { Capitalization } \\
\text { Percentage (\%) }\end{array}$ \\
\hline 1 & Finance & $2.534,93$ & 36,69 \\
\hline 2 & $\begin{array}{l}\text { Consumer } \\
\text { Goods }\end{array}$ & $1.065,45$ & 15,42 \\
\hline 3 & Basic Industry & 758,67 & 10,98 \\
\hline 4 & Infrastructure & 688,02 & 9,96 \\
\hline 5 & Trade & 653,77 & 9,46 \\
\hline 6 & Mining & 425,27 & 6,16 \\
\hline 7 & Property & 380,41 & 5,51 \\
\hline 8 & Miscellaneous & 314,23 & 4,55 \\
\hline 9 & Agriculture & 88,31 & 1,28 \\
\hline
\end{tabular}

The sectoral index that will be selected and studied is the sectoral index that has the five highest rankings in the three determinations which will then be consolidated from the three tables to then equate the values of the three tables. The results of the consolidation show that the selected sectoral indices include consumer goods (JKCONS), basic industry (JKBIND), infrastructure (JKINFA), mining (JKMING) and Finance (JKFINA). The results of the sectoral index consolidation can be seen in table 4.

\begin{tabular}{|c|c|c|}
\hline Rating & Sectoral & Consolidation Value (\%) \\
\hline 1 & Finance & 20,44 \\
\hline 2 & Basic Industry & 15,29 \\
\hline 3 & Mining & 13,33 \\
\hline 4 & Consumer Goods & 12,62 \\
\hline 5 & Infrastructure & 9,86 \\
\hline 6 & Agriculture & 9,12 \\
\hline 7 & Miscellaneous & 8,36 \\
\hline 8 & Trade & 7,54 \\
\hline 9 & Property & 3,43 \\
\hline
\end{tabular}

\section{Selected Issuers}

The criteria for selecting issuers to be included in the first portfolio construction is to have a positive return on assets (ROA) and return on equity (ROE) for 2 years, namely 2018 and 2019. According to Hanafi (2006), the ratio of ROA and ROE can measure the ability the company generates net income with certain asset and share capital indicators. Positive profit for two years, namely 2018 and 2019 is used as an indicator of each issuer in generating profits or profits. The third indicator is not including issuers who did stock splits during 2018 to 2019 to avoid bias that occurs in the calculation of stock returns (Sulistyorini 2009). Issuers and selected sectors can be seen in table 5 .

Table 5 Sector and choosen emiten

\begin{tabular}{|l|l|l|}
\hline \multicolumn{1}{|c|}{ Sektoral } & Kode & \multicolumn{1}{c|}{ Nama } \\
\hline Goods & DLTA & Delta Djakarta Tbk. \\
& HMSP & HM Sampoerna Tbk. \\
& ICBP & Indofood CBP Sukses Makmur Tbk. \\
& MLBI & Mayora Indah Tbk. \\
& UNVR & Industri Jamu dan Farmasi Sido \\
\hline Finance & ADMF & Adira Dinamika Multi Finance Tbk. \\
& BBCA & Bank Central Asia Tbk. \\
& BBRI & Bank Rakyat Indonesia (Persero) \\
& BFIN & BFI Finance Indonesia Tbk. \\
& BTPS & Bank BTPN Syariah Tbk. \\
\hline Basic & CPIN & Charoen Pokphand Indonesia Tbk. \\
Chemicals $\&$ & FASW & Fajar Surya Wisesa Tbk. \\
& JPFA & Japfa Comfeed Indonesia Tbk. \\
& PBID & Panca Budi Idaman Tbk. \\
& TKIM & Pabrik Kertas Tjiwi Kimia Tbk. \\
\hline Mining & ADRO & Adaro Energy Tbk. \\
& BYAN & Bayan Resources Tbk. \\
& ITMG & Indo Tambangraya Megah Tbk. \\
& MYOH & Samindo Resources Tbk. \\
& PTBA & Bukit Asam Tbk. \\
\hline Infrastucture & HITS & Humpuss Intermoda Tbk. \\
& IPCC & Indonesia Kendaraan Terminal Tbk. \\
& JSMR & Jasa Marga Persero Tbk. \\
& PPRE & PP Presisi Tbk. \\
& TLKM & Telekomunikasi Indonesia Tbk. \\
& &
\end{tabular}

\section{Expected Return and Risk}

Table 6 The results of the calculation of the expected return of the selected stocks

\begin{tabular}{|l|c|c|}
\hline No & Stock code & Expected Return COVID Period (\%) \\
\hline 1 & DLTA & $-0,18$ \\
\hline 2 & HMSP & 0,03 \\
\hline 3 & ICBP & $-0,02$ \\
\hline 4 & MLBI & $-0,20$ \\
\hline 5 & UNVR & 0,08 \\
\hline 6 & ADMF & $-0,04$ \\
\hline 7 & BBCA & 0,05 \\
\hline 8 & BBRI & 0,11 \\
\hline 9 & BFIN & 0,01 \\
\hline 10 & BTPS & 0,16 \\
\hline 11 & CPIN & 0,09 \\
\hline 12 & FASW & 0,04 \\
\hline 13 & JPFA & 0,05 \\
\hline 14 & PBID & 0,21 \\
\hline 15 & TKIM & 0,32 \\
\hline 16 & BYAN & 0,05 \\
\hline 17 & ITMG & 0,23 \\
\hline 18 & MYOH & 0,07 \\
\hline 19 & PTBA & 0,14 \\
\hline 20 & ADRO & 0,22 \\
\hline 21 & HITS & $-0,01$ \\
\hline 22 & IPCC & 0,04 \\
\hline 23 & JSMR & 0,04 \\
\hline 24 & PPRE & 0,40 \\
\hline 25 & TLKM & 0,00 \\
\hline & & \\
\hline
\end{tabular}


The expected return value describes the rate of return that investors will get in the future. A positive expected return indicates a potential profit for investors. Vice versa, if the expected return value is negative, it has the potential to provide losses for investors. The results of the calculation of the expected return of the selected stocks can be seen in table 6.

Investors can use market information as a basis for making decisions to carry out investment activities. To obtain market information, it is possible to calculate the expected market return $(\mathrm{E}(\mathrm{Rm}))$ and market risk $(\sigma \mathrm{m} 2)$ obtained from the Jakarta Composite Index (JCI) data. JCI is the overall income from all sectors or companies that have been listed on the Indonesia Stock Exchange (IDX). The calculation is obtained through daily JCI data with two periods, namely the preCOVID period and during COVID. The results of the calculation of the expected market return and market risk for the two different periods can be seen in table 7 .

Table 7 Value of expected market return and market risk in the pre-COVID and COVID period

\begin{tabular}{|c|c|}
\hline Market Expected return $\left(\mathbf{E}\left(\mathbf{R}_{\mathrm{m}}\right)\right)$ & Market Risk $\left(\sigma_{\mathrm{m}}{ }^{2}\right)$ \\
\hline Pre-COVID $-0,12 \%$ & Pre-COVID $0,01 \%$ \\
\hline COVID & COVID \\
\hline
\end{tabular}

Jayati et al (2017) argue that a positive expected return value is able to provide positive expectations for market performance in the future. Table 8 shows that the market expected return during the pre-COVID period has a minus value of 0.12 percent and the COVID period has a market expected return value of 0.06 percent. Meanwhile, the market risk value during the pre-COVID and COVID periods has a value of 0.01 percent and 0.05 percent, respectively. This value on average becomes positive during the pandemic, but with a larger standard deviation it reflects a higher risk during the pandemic, even though it does have a positive average return.

\section{Alpha ( $\alpha)$ and Beta $(\beta)$}

Table 8 Beta and alpha values for issuers in the pre-COVID and COVID periods

\begin{tabular}{|c|c|c|c|c|c|c|c|}
\hline \multicolumn{4}{|c|}{ Pre-COVID } & & \multicolumn{3}{|c|}{ COVID } \\
\hline No & Stock Code & Beta & Alpha & No & Stock Code & Beta & Alpha \\
\hline 1 & DLTA & 0,5061 & $-0,0008$ & 1 & DLTA & 0,4905 & $-0,0021$ \\
\hline 2 & HMSP & 1,6787 & $-0,0012$ & 2 & HMSP & 1,2876 & $-0,0004$ \\
\hline 3 & ICBP & 0,5209 & $-0,0006$ & 3 & ICBP & 0,8999 & $-0,0007$ \\
\hline 4 & MLBI & 0,1198 & $-0,0014$ & 4 & MLBI & 0,5915 & $-0,0023$ \\
\hline 5 & UNVR & 0,7930 & $-0,0015$ & 5 & UNVR & 0,9772 & 0,0002 \\
\hline 6 & ADMF & 0,1936 & $-0,0002$ & 6 & ADMF & 0,8445 & $-0,0009$ \\
\hline 7 & BBCA & 0,8195 & 0,0012 & 7 & BBCA & 1,1829 & $-0,0001$ \\
\hline 8 & BBRI & 1,5139 & 0,0016 & 8 & BBRI & 1,6830 & 0,0001 \\
\hline 9 & BFIN & 0,7690 & $-0,0006$ & 9 & BFIN & 0,5939 & $-0,0003$ \\
\hline 10 & BTPS & 1,0101 & 0,0027 & 10 & BTPS & 1,3020 & 0,0009 \\
\hline 11 & CPIN & 2,2505 & 0,0044 & 11 & CPIN & 1,4344 & 0,0001 \\
\hline 12 & FASW & 0,0606 & $-0,0011$ & 12 & FASW & $-0,0370$ & 0,0004 \\
\hline 13 & JPFA & 1,2110 & 0,0014 & 13 & JPFA & 1,5209 & $-0,0003$ \\
\hline 14 & PBID & 0,5599 & 0,0000 & 14 & PBID & 0,6131 & 0,0017 \\
\hline 15 & TKIM & 2,5144 & $-0,0004$ & 15 & TKIM & 1,6548 & 0,0023 \\
\hline 16 & BYAN & 0,4092 & 0,0013 & 16 & BYAN & 0,0992 & 0,0004 \\
\hline 17 & ITMG & 1,0592 & 0,0005 & 17 & ITMG & 1,2741 & 0,0016 \\
\hline 18 & MYOH & 0,2634 & $-0,0006$ & 18 & $\mathrm{MYOH}$ & 0,6213 & 0,0004 \\
\hline 19 & PTBA & 1,5434 & 0,0015 & 19 & PTBA & 1,4236 & 0,0006 \\
\hline 20 & ADRO & 1,8927 & 0,0025 & 20 & ADRO & 1,4525 & 0,0014 \\
\hline 21 & HITS & 0,4786 & $-0,0002$ & 21 & HITS & 0,1708 & $-0,0002$ \\
\hline 22 & IPCC & 0,7307 & $-0,0061$ & 22 & IPCC & 1,2939 & $-0,0004$ \\
\hline 23 & JSMR & 1,3605 & 0,0007 & 23 & JSMR & 1,3967 & $-0,0004$ \\
\hline 24 & PPRE & 1,1707 & $-0,0043$ & 24 & PPRE & 1,5125 & 0,0032 \\
\hline 25 & TLKM & 0,9484 & $-0,0007$ & 25 & TLKM & 1,1827 & $-0,0007$ \\
\hline
\end{tabular}

Beta $(\beta)$ is a measure of the sensitivity of stock returns to market returns. Alpha $(\alpha)$ is a return component that does not depend on market performance, 
where the return comes from micro events that occur in the company concerned. A positive beta value describes a change in market conditions moving in line with changes in the level of profit of the stock. Alpha value describes the condition of the company's profit level. The variance of the residual error is the magnitude of the deviation or the level of error in the estimation of alpha and beta. The beta and alpha values for issuers in the pre-COVID and COVID periods can be seen in table 8 .

Table 8 shows that the selected stocks in the pre-COVID and COVID periods had positive beta values and only FASW issuers in the COVID period had negative beta values. This positive value means that the profit level of these shares moves in line with changes in market conditions. Stocks that have a beta value of more than one include aggressive stocks that are very sensitive to changes in market conditions. A beta value that is less than one includes stocks that are defensive and less sensitive to changes in market conditions. A negative alpha value means that the company's profit level is not good (Rachmawati et al 2017).

\section{Excess Return to Beta (ERB) and Cut-off Point ( $\left.C^{*}\right)$}

ERB is a measure of the excess return premium to one unit of risk that cannot be diversified as measured by beta. The cut off point $\left(C^{*}\right)$ is the limiting point used to determine whether a stock can be included in the portfolio or not. The value of the cut-off point $\left(\mathrm{C}^{*}\right)$ is the largest $\mathrm{Ci}$ value. Securities that can form an optimal portfolio are securities that have an ERB value greater than or equal to the ERB value at point $\mathrm{C}^{*}$. The results of the calculation of the ERB and $\mathrm{Ci}$ values can be seen in table 9.

Table 9 Calculation of ERB and Ci values for pre-COVID and COVID periods

\begin{tabular}{|r|l|c|c|c|c|c|c|c|}
\hline \multicolumn{3}{|c|}{ Pre-COVID } & \multicolumn{5}{c|}{ COVID } \\
\hline $\mathbf{N}$ & Stock Code & ERB & $\mathbf{C}_{\mathbf{i}}$ & & $\mathbf{N o}$ & Stock Code & ERB & $\mathbf{C}_{\mathbf{i}}$ \\
\hline 1 & DLTA & $-0,0031$ & $-0,0003$ & & 1 & DLTA & $-0,0039$ & $-0,0005$ \\
\hline 2 & HMSP & $-0,0020$ & $-0,0005$ & & 2 & HMSP & 0,0002 & 0,0001 \\
\hline 3 & ICBP & $-0,0026$ & $-0,0002$ & & 3 & ICBP & $-0,0004$ & $-0,0002$ \\
\hline 4 & MLBI & $-0,0141$ & $-0,0001$ & & 4 & MLBI & $-0,0036$ & $-0,0010$ \\
\hline 5 & UNVR & $-0,0033$ & $-0,0006$ & 5 & UNVR & 0,0007 & 0,0003 \\
\hline 6 & ADMF & $-0,0032$ & $-0,0001$ & 6 & ADMF & $-0,0006$ & $-0,0002$ \\
\hline 7 & BBCA & 0,0000 & 0,0000 & & 7 & BBCA & 0,0003 & 0,0002 \\
\hline 8 & BBRI & $-0,0003$ & $-0,0001$ & & 8 & BBRI & 0,0006 & 0,0004 \\
\hline 9 & BFIN & $-0,0022$ & $-0,0002$ & & 9 & BFIN & $-0,0001$ & 0,0000 \\
\hline 1 & BTPS & 0,0013 & 0,0001 & & 10 & BTPS & 0,0011 & 0,0003 \\
\hline 1 & CPIN & 0,0007 & $\mathbf{0 , 0 0 0 2} *$ & & 11 & CPIN & 0,0005 & 0,0003 \\
\hline 1. & FASW & $-0,0212$ & 0,0000 & & 12 & FASW & $-0,0076$ & 0,0000 \\
\hline 1. & JPFA & $-0,0002$ & 0,0000 & & 13 & JPFA & 0,0003 & 0,0001 \\
\hline 15 & PBID & $-0,0015$ & $-0,0001$ & & 14 & PBID & 0,0032 & 0,0005 \\
\hline 1. & TKIM & $-0,0015$ & $-0,0005$ & & 15 & TKIM & 0,0019 & $\mathbf{0 , 0 0 0 8}$ \\
\hline 1 & BYAN & 0,0016 & 0,0000 & & 16 & BYAN & 0,0035 & 0,0000 \\
\hline 1 & ITMG & $-0,0009$ & $-0,0001$ & & 17 & ITMG & 0,0017 & 0,0007 \\
\hline 1 & MYOH & $-0,0041$ & $-0,0001$ & & 18 & MYOH & 0,0010 & 0,0001 \\
\hline 1 & PTBA & $-0,0004$ & $-0,0001$ & & 19 & PTBA & 0,0009 & 0,0004 \\
\hline 2 & ADRO & 0,0000 & 0,0000 & & 20 & ADRO & 0,0015 & 0,0007 \\
\hline 2 & HITS & $-0,0020$ & 0,0000 & & 21 & HITS & $-0,0011$ & 0,0000 \\
\hline 2. & IPCC & $-0,0098$ & $-0,0003$ & & 22 & IPCC & 0,0002 & 0,0001 \\
\hline 2. & JSMR & $-0,0009$ & $-0,0002$ & & 23 & JSMR & 0,0002 & 0,0001 \\
\hline 2. & PPRE & $-0,0050$ & $-0,0004$ & & 24 & PPRE & 0,0026 & 0,0008 \\
\hline 2. & TLKM & $-0,0021$ & $-0,0006$ & & 25 & TLKM & $-0,0001$ & $-0,0001$ \\
\hline
\end{tabular}

Portfolio Proportion, Portfolio Expected Return and Portfolio Risk

The proportion of funds is known by calculating a weighted scale. The weighted scale is calculated based on the individual stock beta divided by the stock residual error variance then multiplied by the Expected Return to Beta (ERB) value minus the cut-off point $\left(\mathrm{C}^{*}\right)$. After that the weighted scale of each known stock is then divided by the total number of weighted scales. 
Figure 1 illustrates the optimal stock portfolio fund allocation in the pre-COVID period with the largest allocation of funds to CPIN at 47.61 percent and the smallest allocation to BYAN with a percentage of 7.46 percent. The optimal allocation of stock portfolio funds during the COVID period with the largest allocation of funds to PBID of 22.57 percent and the smallest allocation of funds to BTPS of 2.8 percent. There is a selection of different proportions of funds because the calculation of the proportion of funds for each share is influenced by the ERB value, cut-off point $\left(\mathrm{C}^{*}\right)$, the value of systematic risk and unsystematic risk (Dahlan et al 2013). The ERB value and the systematic value $(\beta)$ of a stock have a positive correlation with the proportion of funds, which means that if the ERB value and the systematic value of a stock are large, the percentage of the proportion of funds will also be higher. Vice versa. The results of calculating the proportion of optimal stock portfolio funds for the pre-COVID and COVID periods can be seen in Figure 1.

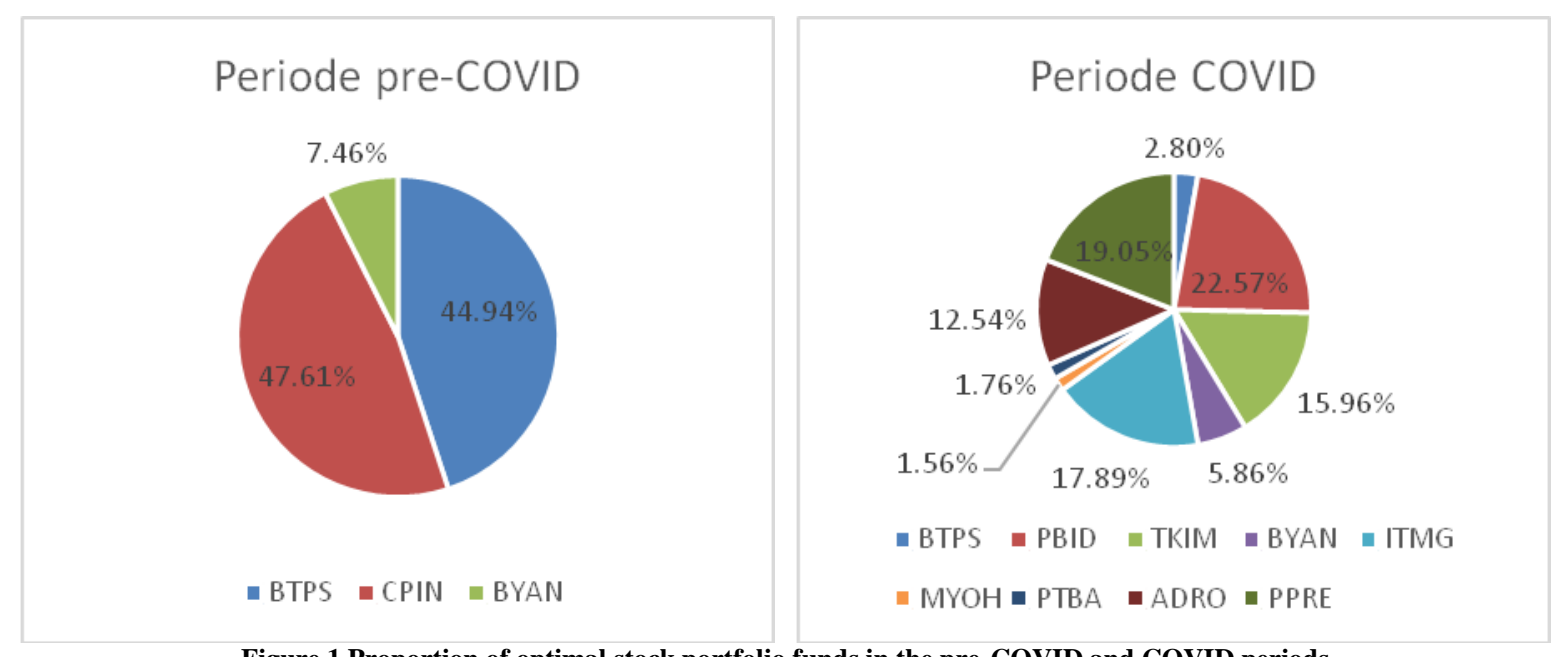

Figure 1 Proportion of optimal stock portfolio funds in the pre-COVID and COVID periods

Investors need to pay attention to the returns and risks of the optimal portfolio that has been formed. The results of the calculations carried out show that the expected return of the optimal stock portfolio in the pre-COVID and COVID periods is positive. This positive value means that it has the potential to provide benefits for investors. The optimal stock portfolio for the pre-COVID period has the potential to provide investors with a profit of 0.15 percent per day with a risk level of 0.05 percent per day. The optimal stock portfolio for the COVID period has the potential to provide investors with a profit of 0.26 percent per day with a risk level of 0.07 percent per day. It can be seen that the optimal stock portfolio in the COVID period provides a higher rate of return than in the pre-COVID period but is also followed by the level of risk. The expected return value and the optimal stock portfolio risk can be seen in table 10.

Table 10 Value of expected return and optimal stock portfolio risk

\begin{tabular}{|cc|lc|}
\hline \multicolumn{2}{|c|}{ Portfolio Expected Return (\%) } & \multicolumn{2}{|l|}{ Portofolio Risk (\%) } \\
\hline Pre-COVID & 0,15 & Pre-COVID & 0,05 \\
\hline COVID & 0,26 & COVID & 0,07 \\
\hline
\end{tabular}

\section{SIM Optimal Portfolio Performance}

The formed portfolio will be evaluated for its stock performance. There are three (3) stock portfolio performance evaluations used in this study, namely the Sharpe method (S), Treynor method (T) and the Jensen method (). In evaluating the performance of stock portfolios, there are similarities between the Sharpe (S) method and the Treynor (T) method. The Sharpe method uses the past average as the expected return and portfolio risk, while the Treynor method uses the same expected return but with beta as a risk measure. Beta indicates that there is a difference between 
changes in the return of a stock portfolio to changes in market returns. The Jensen or Jensen Alpha method uses the CAPM in measuring the portfolio's performance. The optimal stock portfolio performance for the pre-COVID and COVID periods can be seen in full in table 11.

Tabel 11 Optimal portfolio performance in the pre-COVID and COVID periods

\begin{tabular}{|l|c|c|c|}
\hline Periode & $\begin{array}{c}\text { Sharpe Index } \\
(\boldsymbol{\%})\end{array}$ & $\begin{array}{c}\text { Treynor Index } \\
(\boldsymbol{\%})\end{array}$ & $\begin{array}{c}\text { Jensen } \\
\text { Index } \\
(\boldsymbol{\%})\end{array}$ \\
\hline Pre-COVID & 5,92 & 0,09 & 0,35 \\
\hline COVID & 18,42 & 0,21 & 0,19 \\
\hline
\end{tabular}

Table 11 shows a comparison between the three portfolio performance index models with the two methods used in the two different periods, namely the preCOVID period and the COVID period. Portfolio performance measurement uses the Sharpe method which bases the calculation on total risk or standard deviation. The higher the Sharpe ratio value, the better the portfolio performance. The pre-COVID period shows a positive Sharpe portfolio index value and an increase in portfolio value during the COVID period indicates portfolio performance is getting better over time. This positive value which has improved from the pre-COVID period to the COVID period means that the portfolio return formed in the two periods is relatively stable and has good growth prospects and financial conditions in the optimal portfolio.

The measurement of portfolio performance uses the Treynor method which assumes that the portfolio is optimally diversified and only takes into account systematic risk or market risk. Just like the Sharpe index, a positive value in both periods with the COVID period means that the portfolio return formed is better over the current period.

The results of the Jensen method of portfolio performance measurement illustrate that investors have superior or inferior performance to market returns. Portfolio models that have superior performance have a positive Jensen ratio caused by excess returns that occur in the market. On the other hand, the negative Jensen ratio value is caused by the return of the portfolio which is below the expected return of the CAPM. The Jensen ratio in the pre-COVID period recorded a value of 0.35 percent and the resulting value in the COVID period was 0.19 percent. The positive value in both periods reflects the financial manager's performance is better than the market index so that it has a better portfolio return value than its portfolio beta.

\section{CONCLUSIONS}

Based on the analytical steps towards the formation and performance of the portfolio in the pre-COVID and COVID periods, the following conclusions can be drawn:

1. The strategy for compiling portfolios in the pandemic-affected period uses an active strategy approach and a single index model. The use of an active strategy is characterized by using a sector rotation strategy and a stock selection strategy. The use of a sector rotation strategy to select sectors that are expected to experience an increase in certain values which exceed the values in other sectors. The stock selection strategy is carried out by fundamental analysis which is determined in the construction of portfolio formation. The portfolio fund allocation strategy using a single index model calculates the proportion of stock investments in the period before the COVID-19 pandemic in BTPS issuers of 44.94 percent; CPIN is 46.61 percent and BYAN is 7.46 percent. The allocation of funds for the period affected by the COVID-19 pandemic to BTPS issuers is 2.8 percent; PBID of 22.57 percent; TKIM by 15.96 percent; BYAN by 5.86 percent; ITMG by 17.89 percent; MYOH by 1.56 percent; PTBA by 1.76 percent; ADRO is 12.54 percent and PPRE is 19.05 percent.

2. The optimal portfolio of the Single Index Model in the period affected by COVID-19 has better performance than 
the pre-COVID-19 period. The difference is because during the period affected by COVID-19, the stock trend experienced an up or bullish condition. This bullish condition led to a better expected return compared to the preCOVID period. The results of portfolio performance evaluation in both periods are influenced by the resulting portfolio returns. The return and risk of the portfolio in the period before the COVID-19 pandemic were 0.15 percent and 0.05 percent, while in the period affected by the COVID-19 pandemic it was 0.26 percent and 0.07 percent, respectively. The value obtained is in line with the investment principle, namely high risk, high return. The evaluation of portfolio performance in the period affected by COVID-19 has a better value than the pre-COVID-19 period. These results mean that the portfolio formed using a single index model or Single Index Model has a good performance in providing investment shadows through portfolio diversification.

\section{Acknowledgement: None}

\section{Conflict of Interest: None}

\section{Source of Funding: None}

\section{REFERENCES}

1. Ambarita A P, Soekarno S. 2013. Sector rotation investment strategy in indonesia stock exchange. World Applied Sciences Journal. 28(13):60-65. doi:10.5829/idosi.wasj.2013.28.efmo.27011

2. Anggraeni RW, Mispiyanti. 2020. Analisis pembentukan portofolio optimal saham dengan menggunakan model indeks tunggal (studi kasus pada perusahaan terdaftar di indeks SRI-KEHATI periode 2016-2018). Jurnal Ilmiah Mahasiswa Manajemen, Bisnis dan Akuntansi. 2(1):47-54.

3. Bawazier S, Jati PS. 1994. Memilih sahamsaham untuk portofolio optimal. Jurnal Usahawan Tahun XXIII. (1):34-40.
4. Bodie Z, Alex K, Marcus AJ. 2009. Investments: Eighth edition. New York (US): McGraw-Hill.

5. Dahlan S, Topowijono, Zahroh ZA. 2013. Penggunaan single index model dalam analisis portofolio untuk meminimumkan risiko bagi investor di pasar modal (studi pada saham perusahaan yang tercatat dalam indeks LQ-45 di Bursa Efek Indonesia periode 2010-2012). Jurnal Administrasi Bisnis (JAB). 6(2):1-10.

6. Fajri S. 2019. Kajian penerapan strategi investasi aktif di pasar modal indonesia [tesis]. Bogor: Institut Pertanian Bogor.

7. Hanafi. 2006. Analisis laporan keuangan. Yogyakarta: UPP STIM YKPN

8. Hartono J. 2013. Teori Portofolio dan Analisis Investasi. Edisi Kedelapan. BPFE.

9. Husnan S. 2001. Dasar-Dasar Teori Portofolio Dan Analisis Sekuritas. Yogyakarta: AMP YKPN

10. Jayati N, Handayani SR, Zahro ZA. 2017. Analisis metode single index model dalam pembentukan portofolio optimal untuk menurunkan risiko investasi (studi pada perusahaan yang terdaftar dalam indeks IDX30 periode agustus 2013 - juli 2016). Jurnal Administrasi Bisnis (JAB). 49(1):96105.

11. Jogiyanto. 2003. Teori Portofolio dan Analisis Investasi. Edisi Ketujuh. Yogyakarta: BPFE.

12. Jogiyanto. 2010. Teori Portofolio dan Investasi Saham. Yogyakarta: BPFE. Universitas Gadjah Mada.

13. Jones, Utama CPS, Frensidy B, Ekaputra IA, Budiman RU. 2009. Investment Analysis and Management (An Indonesia Adaptation). Indonesia: Salemba Empat and Willey.

14. Jones CP. 2004. Investment: Analysis and Management. Ninth edition. New Jersey (US): John Milley \& Sons, Inc.

15. Klement J. 2011. Investment management is risk management-nothing more, nothing less. Journal of Wealth Management. 14(3):10-16.

16. Marhfor A. 2016. Portofolio performance measurement: review of literature and avenues of future research. American Journal of Industrial and Business Management. 6(4):432-438. doi:10.4236/ajibm.2016.64039

17. Pebrianto F. 2020 Apr 1. Pertumbuhan ekonomi mungkin minus, IHSG dan Rupiah 
jeblok. Tempo.co. Rubrik bisnis. [diakses 2020 Apr 6]. https://bisnis.tempo.co/read/1326629/pertu mbuhan-ekonomi-mungkin-minus-ihsg-danrupiah-jeblok?page_num $=2$

18. Rachmawati FS, Santoso BH. 2017. Analisis portofolio optimal dengan model indeks tunggal pada perusahaan perkebunan yang terdaftar di BEI. Jurnal Ilmu dan Riset Manajemen. 6(8):1-15

19. Rahmasita F, Hidayat RR, Azizah DF. 2014. Pembentukan portofolio optimal dengan menggunakan single index model (studi pada saham-saham sektor industri dasar dan kimia bursa efek indonesia periode 20112013). Jurnal Administrasi Bisnis.16(1):110.

20. Sharpe WF, Alexander GJ, Bailey JV. 1999. Investment. Sixth edition. New Jersey (US): Prentice Hall, Inc.

21. Sidik S. 2020 Des 8. Efek vaksin IHSG mau ke level 6.000, seberapa kuat?. Cnbcindonesia.com. Rubrik market. [diakses $2021 \quad$ Feb 8 . https://www.cnbcindonesia.com/market/202 01208085128-17-207542/efek-vaksin-ihsgmau-ke-level-6000-seberapa-kuat

22. Sulistyorini A. 2009. Analisis kinerja portofolio saham dengan metode Sharpe, Treynor dan Jensen [tesis]. Semarang: Universitas Diponegoro.

23. Tambunan D. 2020. Investasi saham di masa pandemi COVID-19. Widya Cipta: Jurnal Sekretari Dan Manajemen. 4(2):117123. Doi:10.31294/widyacipta.v4i2.8564

24. Zubir Z. 2011. Manajemen Portofolio Penerapannya Dalam Bisnis Investasi Saham. Jakarta (ID): Salemba Empat

How to cite this article: Nugroho SA, Tony Irawan SE MappEc, Ir Aruddy, Msi. Portfolio analysis using the single index method in the COVID-19 pandemic period. International Journal of Research and Review. 2021; 8(6): 215-225. DOI: https://doi.org/10.52403/ijrr. 20210626 